\title{
SIFAT FISIK DAN ORGANOLEPTIK DAGING ITIK LOKAL YANG DIBERI AIR MINUM YANG MENGANDUNG EKSTRAK DAUN SALAM (SYZYGIUM POLYANTHUM)
}

\section{ORGANOLEPTIC AND PHYSICAL CHARACTERISTICS OF MEAT OF LOCAL DUCKS GIVEN INDONESIAN BAY LEAF (SYZYGIUM POLYANTHUM) EXTRACT}

\author{
Hariyadi' ${ }^{1 a}$, Anggraeni1, dan R Handarini
}

1Programstudi Peternakan Fakultas Pertanian Universitas Djuanda Bogor, Jl. Tol Ciawi No. 1, Kotak Pos 35 Ciawi, Bogor 16720.

aKorespondensi: Hariyadi, E-mail: Hariyadi.1509@gmail.com

\begin{abstract}
In addition to chicken, duck is a potential meat producing poultry. Compared to chickens, duck is more resistant to diseases and able to live in feed restricted areas. These superior characteristics make duck rearing relatively less risky. Indonesian bay leaf (IBL) extract is known to contain substances which have antiviral, antimicrobial, antiinflammatory, antitumour, and antioxidative properties. This study was aimed at assessing the effects of the inclusion of IBL extract in drinking water on the organoleptic characteristics of duck (Anas platyrhynchos) meat. The study was conducted at the poultry farm of Djuanda University, Bogor in March to May 2019. One-hundred Mojosari Albio ducks aged 7 days were were allocated into 3 treatments and 6 replicates in a completely randomized design. Four ducks were allocated into each experimental unit. Treatments consisted of the inclusions of IBL extract in drinking water by $0 \%$ (R0, control), 4\% (R1), and 8\% (R2). Data were subjected to a Kruskal Wallis test and a Duncan test. Measurements were taken on hedonic test, hedonic quality test, and physical test parameters. Results showed that the inclusion of IBL extract in drinking water of ducks gave significant effects $(\mathrm{P}<0.05)$ on meat taste and juiceness. It was concluded that IBL extract can be included in drinking water of ducks up to $4 \%$.
\end{abstract}

Key words: mojosari alabio duck, Indonesian bay leaf extract, hedonic test, hedonic quality test, physical test

\section{ABSTRAK}

Ternak itik merupakan unggas yang menghasilkan daging memiliki kemampuan disamping ayam. Ternak itik memiliki keunggulan yang relatif lebih kuat terhadap penyakit dan mampu hidup di lokasi yang kekurangan pakan dibandingkan ayam ras sehingga pemeliharaannya relativ lebih rendah resiko. Kandungan EDS memiliki manfaat sebagai antivirus, antimikroba, antiinflamasi, antitumor, dan antioksidan sebagai system pertahanan tubuh. Tujuan Penelitian untuk menguji pengaruh pemberian ekstrak daun salam (Syzygium polyanthum) terhadap organoleptik daging itik (Anas Platyrhynchos). Penelitian ini dilakukan dikandang unggas Universitas Djuanda Bogor pada bulan Maret - Mei 2019. 100 ekor ternak mojosari alabio yang digunakan dalam penelitian ini berumur 7 hari. Penelitian ini menggunakan rancangan acak lengkap (RAL) yang terdiri atas tiga perlakuan dan enam ulangan, tiap perlakuan terdiri atas 4 ekor itik. Perlakuan dalam penelitian ini adalah pemberian ekstrak daun salam dalam air minum dengan level: $\mathrm{R} 0=0 \%$, (Kontrol), R1=4\%, dan $\mathrm{R} 2=8 \%$. Data diperoleh kemudian dianalisis menggunakan uji Kruskal Wallis, bila data menunjukkan hasil berbeda nyata $(\mathrm{P}<0,05)$ atau sangat nyata $(\mathrm{P}<0,01)$ dilanjutkan menggunakan uji Duncan. Peubah yang diamati pada penelitian ini yaitu uji hedonik, uji mutu hedonik, dan uji fisik. Hasil penelitian menunjukkan daging itik yang diberi ekstrak daun salam menunjukkan pengaruh berbeda nyata $(\mathrm{P}<0.05)$ pada peubah rasa dan juiceness. Kesimpulan penelitian ini yaitu pemberian ekstrak daun salam dapat diberikan pada itik sampai level $4 \%$.

Kata Kunci: $\quad$ itik mojosari alabio, ekstrak daun salam, uji hedonik, uji mutu hedonik, uji fisik.

Hariyadi, Anggraeni, R Handarini. 2020. Sifat fisik dan organoleptik Daging Itik Lokal Yang DIberi minum Yang mengandung Ekstrak Daun Salam (Syzygium Polyanthum). Jurnal Peternakan Nusantara 6(1): 5-14. 


\section{PENDAHULUAN}

Itik adalah unggas penghasil daging yang cukup potensial disamping ayam. Ternak itik memiliki keunggulan yang relatif lebih kuat terhadap penyakit dan mampu hidup di lokasi yang kekurangan pakan dibandingkan ayam ras sehingga pemeliharaannya relative rendah resiko. Salah satu sumber protein yang bermutu tinggi yaitu daging itik, karena itu produksi dagingnya di tujukan kepada konsumen agar mampu memenuhi kebutuhan sumber protein. Faktor-faktor yang mempengaruhi kualitas sensoris daging adalah jenis ternak, umur, pakan cara pemeliharaan, selain itu juga cara penanganan hewan sebelum dipotong, sebelum daging dikonsumsi saat pemotongan dan penanganan daging juga mempengaruhi kualitas sensoris (Suryaningsih et al. 2012).

Daging itik memiliki ciri yang khas diantaranya memiliki serat yang kasar, warnanya agak kemerahan dan memiliki aroma yang agak amis. Daging itik belum banyak dikonsumsi oleh konsumen karena bau khas daging yang tidak disukai yaitu anyir. Faktor bau ini diduga penyebab terhadap daya suka konsumen. Warna khas daging itik yaitu merah gelap, perbedaan daging itik lebih alot dibandingkan dengan ayam sehingga mempengaruhi tingkat kesukaan konsumen terhadap daging itik (Matitaputty dan Suryana 2010).

Didalam daun salam terdapat flavonoid (quercetin, myrcetin dan myrcitrin), tanin, fenol, minyak atsiri (salamol dan eugenol), lakto, saponin, seskuiterpen, triterpenoid, steroid, sital, dan karbohidrat. Fenol mampu menstabilkan radikal bebas karena memiliki fungsi sebagai antioksidan, pembentukan aroma salamol juga dibantu oleh senyawa fenol yang dapat memberikan aroma khas terhadap produk yang diberikan. Flavonoid yang terkandung pada daun salam meyebabkan daun salam memiliki daya antibakteri/antimikroba (Widiawati 2005). Tujuan untuk menguji kualitas fisik dan sensoris daging itik lokal yang diberi ekstrak daun salam dalam air minumnya.

\section{MATERI DAN METODE}

\section{Materi}

Penelitian ini akan dilaksanakan pada bulan Maret sampai bulan Mei 2019 di kandang unggas Program Studi Peternakan Fakultas Pertanian, uji sensorik dilakukan di Lab Universitas Djuanda Bogor.

Itik jantan (DOD) umur 1 hari sebanyak100 ekor, EDS, dan pakan komersil dengan kandungan 21.0 - 23.0 $\%$. Bahan untuk uji sensorik: kertas label, tusuk gigi dan form penilaian uji hedonik dan uji mutu hedonik. Jumlah panelis yang terlibat dalam uji sensorik sebanyak 60 orang fanelis dengan kriteria panelis semi terlatih.

Ukuran kandang 75 X 75 X $50 \mathrm{~cm}$ sebanyak 18 buah kemudian diisi 4 ekor itik per unit kandang secara acak yang dilengkapi tempat pakan dan minum dan lampu 60 watt. Alat untuk membuat ekstrak daun salam: tabung gas, kompor, panci, baskom, parutan, saringan nasi, ember besar, pisau, gelas ukur ukuran $100 \mathrm{ml}, 500 \mathrm{ml}$, dan 1000 $\mathrm{ml}$ dan timbangan. Alat untuk uji sensoris yaitu: pisau, plastic, cuttter, nampan, alat tulis, alat dokumentasi, sterofom.

\section{Perlakuan}

Perlakuan yang akan diberikan sebagai berikut:

$\mathrm{A}_{0}=$ air minum tanpa pemberian ekstrak daun salam (kontrol).

$\mathrm{A}_{1}=$ air minum mengandung $4 \%$ ekstrak daun salam.

$\mathrm{A}_{2}=$ air minum mengandung $8 \%$ ekstrak daun salam. 


\section{Rancangan Percobaan}

Penelitian ini memakai metode rancangan acak lengkap (RAL) tiga perlakuan enam ulangan. Berikut model matematika yang digunakan dalam penelitian (Hanafiah 2003):

$$
\mathrm{Yij}=\mu+\mathrm{Ti}+\varepsilon \mathrm{ij}
$$

$$
\text { Keterangan: Yij = Nilai }
$$
pengamatan dari perlakuan ke-I pada ulangan ke-j.

$\mu=$ Nilai tengah umum.

$\mathrm{T}_{i}=$ Pengaruh persentase ekstrak daun salamke-i.

$\varepsilon_{i j}=$ Pengaruh galat percobaan padapersentase ekstrak daun salam ke-i ( $\mathrm{i}=1,2,3)$ ada persentase ekstrak daun salampada ulangan ke-j. $(j=1,2,3,4,5,6)$

\section{Peubah yang Diamati}

Peubah yang diamati yaitu uji hedonik, uji mutu hedonic dan uji fisik. Uji hedonik dilakukan agar mendapatkan tingkat kesukaan panelis terhadap produk. Panelis diminta memberikan penilaian tingkat kesukaannya dengan kisaran 1 5 (1= sangat tidak suka, $2=$ tidak suka, $3=$ netral, $4=$ suka, $5=$ =sangat suka). Parameter uji dan mutu hedonic meliputi, aroma, warna, keempukkan, rasa dan juiceness. Diberi 3 kode angka pada setiap perlakuan yang diletakkan di atas sterofoam berisi sampel. Lima kategori peubah dan skor penilaian disajikan pada Tabel 1 .

\section{Analisis Data}

Data yang diperoleh dianalisis dengan sidik ragam (ANOVA) dan jika perlakuan berpengaruh nyata terhadap peubah yang diamati maka analisis dilanjutkan dengan uji lanjut jarak ganda Duncan dengan menggunakan bantuan piranti program SPSS 16.

\section{Prosedur Pelaksanaan}

Lingkungan kandang dibersihkan dan diberi sumber penerangan. Kandang dan peralatan disiapkan. Pemasangan tempat pakan dan minum di pasang disekat kandang dan dipasangkan karpet untuk menampung feses.

100 ekor itik dengan umur 7 hari dalam kondisi sehat, dan tidak cacat. Adaptasi lingkungan selama 7 hari dengan catatan bobot badan awal dan diberikan catatan identitas perlakuan pada kandang serta no identitas yang ditempelkan pada kaki, penempatan kandang dan perlakuan dilakukan secara acak.Proses pembuatan larutan daun salam dapat dilihat pada Gambar 1.

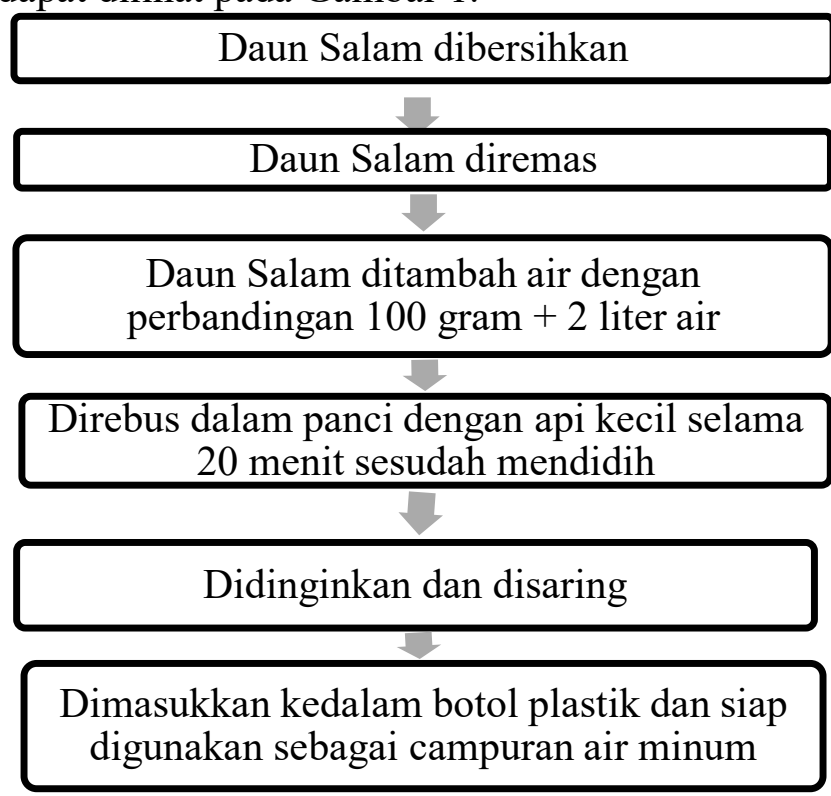

Gambar 1 Proses pembuatan EDS

Pemberian pakan dan minum dilakukan 1 kali sehari pada pukul 09.00 WIB. Rangkaian kegiatan lain yaitu, bersih kandang, penggantian air minum, pakan komersil, pembersihan alas feses, penimbangan sisa pakan dan pemberian pakan. Pemberian ekstrak daun salam pada ternak, diberikan dengan cara dicampurkan dalam air minum. Pemberian ekstrak daun salam dalam perlakuan sesuai Tabel 2 .

Tabel 2 EDS sesuai perlakuan

\begin{tabular}{ccc}
\hline Perlakuan & EDS (ml) & $\begin{array}{c}\text { Air minum } \\
(\mathrm{ml})\end{array}$ \\
\hline A0 & $0 \mathrm{ml}$ & 3000 \\
A1 & $120 \mathrm{ml}$ & 2880
\end{tabular}




\begin{tabular}{|c|c|c|}
\hline A2 & 240 & 2760 \\
\hline Tabel 1 Skor Pe & laian U & i Mutu Hedonik. \\
\hline Peubah & Skor & Kriteria \\
\hline Aroma & 1 & Tidak \\
\hline & & beraroma amis \\
\hline & 2 & Sedikit \\
\hline & & beraroma amis \\
\hline & 3 & Cukup \\
\hline & & beraroma amis \\
\hline & 4 & Beraroma \\
\hline & & amis \\
\hline & 5 & Sangat \\
\hline & & beraroma amis \\
\hline Keempukkan & 1 & Tidak empuk \\
\hline & 2 & Sedikit empuk \\
\hline & 3 & Cukup empuk \\
\hline & 4 & Empuk \\
\hline & 5 & Sangat empuk \\
\hline Warna & 1 & PutihMerah \\
\hline & 2 & Putih pucat \\
\hline & 3 & Merah muda \\
\hline & 4 & Merah cerah \\
\hline & 5 & Gelap \\
\hline Rasa & 1 & $\begin{array}{l}\text { Sangat tidak } \\
\text { enak }\end{array}$ \\
\hline & 2 & Tidak Enak \\
\hline & 3 & Netral \\
\hline & 4 & Enak \\
\hline & 5 & Sangat enak \\
\hline Juiceness & 1 & $\begin{array}{l}\text { Tidak } \\
\text { juiceness }\end{array}$ \\
\hline & 2 & $\begin{array}{l}\text { Sedikit } \\
\text { juiceness }\end{array}$ \\
\hline & 3 & Juiceness \\
\hline & 4 & Lebih \\
\hline & & Juiceness \\
\hline & 5 & $\begin{array}{l}\text { Sangat } \\
\text { juiceness }\end{array}$ \\
\hline
\end{tabular}

Pada akhir penelitian dilakukan pemotongan itik yang berumur 60 hari dari seluruh perlakuan secara syariat Islam, metode pemotongan dengan memutuskan arteri karotis, vena jugularis dan esophagus yang berada antara kepala dan leher. Itik yang sudah dipotong kemudian digantung kakinnya agar darah mengalir keluar, itik dimasukan kedalam air mendidih untuk memudahkan pencabutan bulu setelah itu dilakukan pengkarkasan dan pengambilan daging bagian paha dan dada. Daging dada dan paha, masingmasing sampel sesuai perlakuan direbus selama lima belas menit. Daging dipotong dengan ukuran $2 \times 2 \times 1 \mathrm{~cm}$, disajikan diatas piring sterofoam.

Sebelum penelitian dilakukan peralatan dan bahan disiapkan. Kandang individu untuk penggemukan domba yang berbentuk panggung dan bercelah dari bambu, disiapkan dan dibersihkan. Domba yang akan diteliti diperiksa kondisi kesehatannya, tidak cacat, dan berumur kurang dari satu tahun. Selanjutnya, dilakukan pencukuran bulu dan pemberian obat cacing. Domba yang telah dicukur tersebut lalu ditimbang dan lalu ditempatkan secara acak ke dalam kandang individu. Selanjutnya diberi kode sebanyak tiga digit pada setiap piring sampel. Panelis yang digunakan adalah panelis semi terlatih sebanyak 60 orang. Pertama Panelis diberi pengarahan oleh tim peneliti tentang mengisi formulir. Panelis akan menilai sample daging yang diletakkan pada wadah kecil dengan kode yang telah ditentukan peneliti.

\section{HASIL DAN PEMBAHASAN}

\section{Uji Hedonik}

Salah satu pengujian yang dilakukan pada penelitian ini yaitu prganoleptik. Pengertian uji organoleptik disebut juga sebagai penilaian indra atau penillaian sensorik. Menurut Ayustaningwarno (2014) tujian indera manusia untuk Uji organoletik yaitu mengamati keempukkan, warna, rasa, aroma, suatu produk makanan, minuman ataupun obat, dalam kasus ini yaitu daging itik.

Uji organoleptik dilakukan yaitu uji hedonik Menurut Setyaningsih et al. (2010) dilakuakan uji hedonnik untuk mengetahui tanggapan panelis terhadap 
kesukaan atau ketidak sukaannya suatu produk. Tujuan pengujian organoleptik untuk mengklarifikasi persepsi masyarakat mengenai daging itik, yang sebelumnya telah dilakukan tahapan wawancara. Persepsi yang diasumsikan sebelumnya oleh masyarakat hanya menurut pendapat mereka tanpa melihat fisik daging secara langsung, namun dengan pengujian organoleptik masyarakat melakukan penilaian dengan melihat langsung fisik daging yang diujikan. Rataan nilai uji hedonik daging itik bisa dilihat pada Tabel 3.

Tabel 3 Rataan Nilai Uji Hedonik Daging Itik

\begin{tabular}{lccc}
\hline \multirow{2}{*}{ Peubah } & \multicolumn{3}{c}{ Perlakuan } \\
\cline { 2 - 4 } & R0 & R1 & R2 \\
\hline Aroma & $3,20 \pm 0,77$ & $3,53 \pm 0,73$ & $3,53 \pm 0,77$ \\
Keemp & $3,49 \pm 0,93$ & $3,46 \pm 1,08$ & $3,23 \pm 0,92$ \\
ukan & & & \\
Warna & $3,23 \pm 0,84$ & $3,23 \pm 0,78$ & $3,13 \pm 0,74$ \\
Rasa & $3,25 \pm 0,93$ & $3,37 \pm 0,98$ & $3,28 \pm 0,77$ \\
Juicene & $3,53 \pm 0,90$ & $3,30 \pm 0,80$ & $3,13 \pm 0,89$ \\
ss & & & \\
\hline
\end{tabular}

Keterangan: R0 $=0 \%$ ekstrak daun salam, R1 $=4 \%$ ekstrak daun salam, R2 $=8 \%$ ekstrak daun salam. Jumlah panelis 60 orang

Berdasarkan hasil analisis Kruskal Wallis dari setiap perlakuan memberikan pengaruh tidak nyata $(\mathrm{P}>0,05)$ terhadap peubah aroma, keempukan, warna, rasa, juiceness. Uji hedonik aroma daging memberikann rataan $3,42 \pm 0,02$ dengan kisaran $3,20 \pm 0,77-3,53 \pm 0,77$. Nilai rataan aroma 3 menunjukkan tingkat kesukaan panelis terhadap aroma daging itik netral.

Berdasarkan hasil analisis Kruskal Wallis pada peubah keempukan daging itik menunjukan pengaruh tidak berbeda nyata $(\mathrm{P}>0,05)$. Uji hedonik keempukan daging itik menghasilkan rataan nilai $3,39 \pm 0,09$ dengan kisaran 3,23 $\pm 0,92-$ $3,49 \pm 0,93$. Nilai rataan keempukan 3 menunjukkan keempukan daging itik netral.

Uji hedonik warna daging itik memberikan nilai rataan $3,20 \pm 0,05$ dengan kisaran $3,13 \pm 0,74-3,23 \pm 0,84$, angka tersebut menunjukan warna daging itik netral.

Berdasarkan hasil analisis Kruskal Wallis bahwa pada rasa menunjukan $(P>0,05)$. Uji hedonik rasa daging itik menghasilkan rataan nilai $3,30 \pm$ 0.11dengan kisaran 3,25 $\pm 0,93-3,37 \pm$ 0,98 . Nilai rataan rasa 3 menunjukkan daging itik netral.

Hasil analisis Kruskal Wallis pada peubah juiceness daging itik menunjukan pengaruh $(\mathrm{P}>0,05)$. Uji hedonik juiceness daging itik memberikan nilai rataan 3.32 \pm 0.06dengan kisaran 3,13 $\pm 0,89-3,53 \pm$ 0,90 , angka tersebut menunjukan juiceness daging itik netral.

\section{Uji Mutu Hedonik}

Uji mutu hedonik meliputi aroma, keempukan, warna, rasa, dan juiceness dengan penilaian 1 - 5 yang lebih jelas (Tabel 4). Penilaian mutu hedonik diberikan panelis sesuai dengan alat indera yaitu mata (penglihatan), hidung (penciuman), dan lidah (pengecap rasa). Hasil rataan disajikan dalam Tabel 4. Secara umum perlakuan pemberian EDS $(\mathrm{P}>0.05)$ pada peubah aroma, keempukan dan warna. Namun memberikan pengaruh nyata $(\mathrm{P}<0.05)$ pada peubah rasa dan juiceness.

Tabel 4 Rataan uji mutu hedonik daging itik yang diberi ekstrak daun salam

\begin{tabular}{|c|c|c|c|}
\hline \multirow{2}{*}{ Peubah } & \multicolumn{3}{|c|}{ Perlakuan } \\
\hline & R0 & $\mathrm{R} 1$ & $\mathrm{R} 2$ \\
\hline Aroma & $2,90 \pm 1,30$ & $2,90 \pm 1,30$ & $2,45 \pm 1,16$ \\
\hline $\begin{array}{l}\text { Keempuk } \\
\text { an }\end{array}$ & $3,55 \pm 0,95$ & $2,98 \pm 1,10$ & $2,82 \pm 1,13$ \\
\hline Warna & $1,67 \pm 0,90$ & $1,50 \pm 0,83$ & $1,77 \pm 0,72$ \\
\hline Rasa & $3,67 \pm 0,82^{\mathrm{a}}$ & $3,60 \pm 0,81^{\mathrm{a}}$ & $3,15 \pm 1,01^{b}$ \\
\hline Juiceness & $2,65 \pm 1,12^{\mathrm{a}}$ & $2,58 \pm 1,18^{\mathrm{a}}$ & $2,32 \pm 1,05^{\mathrm{b}}$ \\
\hline $\begin{array}{l}\text { Keterangar } \\
=4 \% \text { ekst } \\
\text { daun salan }\end{array}$ & $\begin{array}{l}\mathrm{R} 0=0 \% \text { eks } \\
\mathrm{k} \text { daun sala } \\
\text { umlah panel }\end{array}$ & $\begin{array}{l}\text { ak daun salar } \\
\text { R2 = 8\% ek } \\
60 \text { orang. }\end{array}$ & $\begin{array}{l}\text { R1 } \\
\text { trak }\end{array}$ \\
\hline
\end{tabular}

Berdasarkan hasil analisis Kruskal Wallis, pemberian perlakuan ekstrak daun salam pada peubah aroma daging itik menunjukan hasil yang tidak berbeda 
nyata $(\mathrm{P}>0,05)$. aroma daging itik memberikan nilai rataan $2.75 \pm 0.08$ dengan kisaran 2,45 $\pm 1,16-2,90 \pm 1,30$. Rataan nilai uji mutu hedonik terhadap aroma 2 menunjukkan bahwa panelis merasakan bahwa daging itik sedikit beraroma amis.

Berdasarkan hasil analisis kruskal wallis, pada peubah keempukkan daging itik menunjukkan hasil yang tidak berbeda $(P>0,05)$. keempukkan daging itik dengan nilai tertinggi ada pada perlakuan R0 dengan nilai 3,55 menunjukkan keempukkan daging itik cukup empuk, R2 dengan nilai 2,82 menunjukkan nilai terendah dan menghasilkan daging itik sedikit empuk.

Berdasarkan hasil analisis kruskal wallis pada peubah warna daging itik menunjukkan hasil yang tidak berbeda nyata $(\mathrm{P}>0.05)$ dengan nilai tertinggi ada pada perlakuan R2 dengan nilai1,77 menunjukkan warna daging itik putih merah, sedangan nilai terendah di R1 dengan nilai 1,50 menunjukkan daging itik berwarna putih merah.

Pada peubah rasa daging itik menunjukkan hasil yang berbeda nyata $(\mathrm{P}<0.05)$ terhadap rasa daging itik. Pada Tabel 5 diketahui bahwa perlakuan R0 dan R1 tidak berbeda nyata tapi berbeda dengan R2. Penambahan sebanyak $8 \%$ menghasilkan rasa yang netral. Berbeda halnya hasil perlakuan R0 (control) dan penambahan 4\% (R1) menghasilkan rasa yang netral cenderung enak. Dengan kata lain $4 \%$ dianggap optimal menghasilkan rasa yang cenderung enak.

Berdasarkan hasil analisis kruskal wallis, diketahui pada peubah juiceness daging itik menunjukkan hasil yang berbeda nyata $(\mathrm{P}<0.05)$. Juiceness daging itik yang mendapat perlakuan 8\% (R2) berbeda nyata $(\mathrm{P}<0.05)$ dengan $\mathrm{R} 0$ dan R1. Penambahan hingga $4 \%$ menghasilkan daging yang agak juiceness, sedangkan penambahan $8 \%$ menghasilkan daging sedikit juiceness atau berkurangnya kadar juiceness.

\section{Uji Fisik}

indikator penting dalam menilai kualitas fisik daging yaitu Nilai $\mathrm{pH}, \mathrm{SM}$, DMA. Ketiga indikator tersebut menentukan tingkat kualitas dan keawetan. Adapun Hasil penilaian kualitas daging disajikan pada Tabel 5.

Tabel 5 Rataan uji fisik daging itik yang diberi ekstrak daun salam

\begin{tabular}{lccc}
\hline & \multicolumn{3}{c}{ Perlakuan } \\
\cline { 2 - 4 } & R0 & R1 & R2 \\
\hline pH & $5,81 \pm 0,6^{\mathrm{a}}$ & $6,43 \pm 0,3^{\mathrm{b}}$ & $6,43 \pm 0,2^{\mathrm{b}}$ \\
$\mathrm{SM}$ & $50,68 \pm 2,2^{\mathrm{c}}$ & $43,26 \pm 1,3^{\mathrm{a}}$ & $49,65 \pm 2,1^{\mathrm{b}}$ \\
DMA & $32,04 \pm 0,9^{\mathrm{a}}$ & $32,19 \pm 0,5^{\mathrm{a}}$ & $32,44 \pm 0,7^{\mathrm{b}}$
\end{tabular}

Keterangan: R0 = 0\% ektsrak daun salam, R1 $=4 \%$ ekstrak daun salam, R2 $=8 \%$ ekstrak daun salam. $\mathrm{pH}=$ Power of Hydrogen $\mathrm{SM}=$ susut masak, DMA = daya mengikat.air.

Power of Hydrogen (pH)

Pada saat ternak masih hidup, $\mathrm{pH}$ daging berkisar 7.2 - 7.4 (Lawrie 2003). Pada hasil penelitian ini menunjukkan peningkatan $\mathrm{pH}$ daging itik berkisar 6.43 dibandingkan dengan kontrol. Nilai $\mathrm{pH}$ dibawah hasil penelitian Lukman (1995) berkisar 6.12 - 7.71. Penurunan $\mathrm{pH}$ daging setelah proses pemotongan terjadi glikolisis anaerob menghasilkan asam laktat (Aberle et al. 2001).

Hasil analisis keragaman menunjukkan bahwa daging itik yang berasal dari itik yang diberi EDS memberikan pengaruh berbeda nyata $(\mathrm{P}<0.05)$ dalam menaikkan nilai $\mathrm{pH}$ daging itik. Tabel 6 memperlihatkan bahwa rataan nilai $\mathrm{pH}$ daging itik perlakuan R0 yakni pemberian air 100\% memiliki nilai lebih rendah yakni 5,81 dibandingkan dengan perlakuan lainnya yang diberikan campuran ekstrak daun salam. Nilai tertinggi ada pada perlakuan $\mathrm{R} 1$ dan R2 yakni 6.43 menghasilkan $\mathrm{pH}$ yang normal. 
Susut Masak (SM)

Susut masak daging adalah proporsi berat daging yang hilang selama proses pemasakan atau pemanasan. Hasil analisis statistik menunjukan bahwa persentase susut masak daging itik. pada lokasi otot yang berbeda menunjukan berbeda nyata $(\mathrm{P}<0.05)$. Rataan susut masak daging itik hasil penelitian ini pada (tabel 6) memperlihatkan bahwa rataan daging itik perlakuan R0 yakni pemberian air $100 \%$ tanpa penambahan EDS memiliki nilai lebih tinggi yakni $50,68 \pm 2,21$ dibandingkan dengan nilai lainnya yang diberikan campuran EDS. Nilai terendah ada pada perlakuan R1 yakni pemanbahan ekstrak daun salam 4\% memiliki nilai lebih rendah yakni 43,26 \pm 1,13. Soeparno (2009) menyatakan bahwa kualitas daging yang lebih baik yaitu pada saat jumlah susut masak yang rendah, karena hilangnya nutrisi pada perebusan akan semakin sedikit. Tingginya SM dipengaruhi oleh $\mathrm{pH}$, panjang pemotongan serabut otot, panjang sarkomer serabut otot, status kontraksi myofibril, ukuran dan berat sampel daging. variasi susut masak antara $1,5 \%$ sampai $54,5 \%$.

\section{Daya Mengikat Air (DMA)}

Berdasarkan hasil anova, pada peubah DMA daging itik menunjukan hasil yang berbeda nyata $(\mathrm{P}<0,05)$. Rataan DMA daging itik pada (tabel 6) diketahui bahwa perlakuan R0 dan R1 tidak berbeda nyata tapi berbeda dengan R2. Data tersebut menunjukkan bahwa penambahan EDS sebanyak 8\% menghasilkan DMA yang lebih tinggi. Semakin banyak air bebas yang keluar atau nilai mgH2O yang semakin tinggi maka kemampuan daya menigkat air daging semakin rendah (Honikel 1998). Lawrie (2003) dan Komariah et al. (2009) menjelaskan bahwa marbling yang tinggi cenderung mempunyai nilai DMA tinggi atau nilai mgH2O4 rendah.

Faktor yang mempengaruhi DMA diantaranya adalah $\mathrm{pH}$, temperatur, proses pelayuan, pemasakan, protein otot, spesies, fungsi otot, umur, pakan, penyimpanan, jenis kelamin, perlakuan sebelum pemotongan, dan marbling (Soeparno 2005).

\section{KESIMPULAN DAN IMPLIKASI}

\section{Kesimpulan}

Perlakuan penambahan hingga 8\% tidak berpengaruh terhadap uji hedonik. Berbeda halnya pada uji mutu hedonik yaitu rasa dan juiceness, dipengaruhi secara nyata oleh ekstrak daun salam pada air minum. Berdasarkan hasil penelitian pemberian (EDS) yang optimal adalah 4\%. Pemberian 8\% EDS menyebabkan mengurangi rasa enak dan menurunkan juiceness.

Pemberian EDS pada air minum berpengaruh terhadap uji fisik, yaitu ph,susut masak dan DMA pada kualitas daging itik. Semakin tinggi daya mengikat air maka semakin rendah susut masak pada daging itik.

\section{Implikasi}

Pemberian EDS dalam air minum sebaiknya tidak lebih dari $4 \%$ agar mendapatkan hasilkan kualitas daging yang baik.

\section{DAFTAR PUSTAKA}

Hanafiah KA. 2003. Rancangan Percobaan Teori dan Aplikasi. Raja Grafindo Persada, Jakarta

Matitaputty PR, Suryana. 2010. Karakteristik Daging Itik dan Permasalahan serta Upaya Pencegahan off-flavor Akibat Oksidasi Lipida.Wartazoa Vol. 20 (3): 130 138.

Matitaputty PR. 2012.Peningkatan produktivitas karkas dan kualitas daging itik melalui silangan antara itik cihateup dan alabio.[Disertasi]. Bogor (ID): Institut Pertanian Bogor. 
[National Research Council]. 1994. Nutrient Requirement of Poultry: Ninth Revised Edition.National Academy Press. Washington DC. USA

Setyaningsih D, Apriyantono A, Sari MP. 2010. Analisa Sensori Food and Agro Industry. IPB Press, Bogor

Soeparno. 2009. . Meat Science and Technology.Yogyakarta (ID). Gajah Mada Univ Press.

Soeparno. 2005. Meat Science and Technology. Gajah Mada University Press, Yogyakarta
Suryaningsih L, Wendry SP, Eka W. 2012. Pengaruh Perendaman Daging Itik Pada Berbagai Konsentrasi Ekstrak Kunyit (Curcuma Domestika) Terhadap Warna, Rasa, Bau, dan pH. Jurnal Ilmu Ternak.Vol.12 (1): 24 - 28.

Widiawati AW. 2005. Potential of Salam Leaves (Syzygium polyanthum) and Black Cumin Seeds (Nigella sativa Linn) as Candidates for Acid-Based Herbal Medicines Urat.Pharmacon. 13(1):30 - 36 .

Winarno FG. 2004. Kimia Pangan. PT. Gramedia Pustaka Utama. Jakarta. 
